\title{
Tracing the flows of knowledge transfer: Latent dimensions and determinants of university-industry interactions in peripheral innovation systems
}

\author{
Manuel Fernández-Esquinas a ${ }^{\text {, Hugo Pinto }}{ }^{\text {b,c,* }}$, Manuel Pérez Yruela ${ }^{\text {a }}$, Tiago Santos Pereira ${ }^{\text {b }}$ \\ a Institute for Advanced Social Studies (IESA), Consejo Superior de Investigaciones Científicas (CSIC), Spain \\ b Centre for Social Studies, University of Coimbra, Portugal \\ ${ }^{\mathrm{c}}$ Faculty of Economics, University of Algarve, Portugal
}

\section{A R T I C L E I N F O}

\section{Article history:}

Received 12 May 2014

Received in revised form 7 June 2015

Accepted 17 July 2015

Available online 5 August 2015

\section{Keywords:}

Firms

Innovation

Knowledge transfer

Peripheral regions

University-industry interactions

Cluster analysis

\begin{abstract}
A B S T R A C T
Firms interact with universities through a variety of channels, ranging from collaborative research projects, patents, spin-off creation, consultancy and specialized training, to informal relationships. This article explores the combination of mechanisms used by firms in Andalusia, a peripheral region in Spain and Europe, when interacting with universities. Using information from a survey of 737 innovative firms, the empirical study found evidence that university-industry links can be grouped into five latent dimensions (knowledge generation and adaptation, involvement in new organisations, training and exchange of human resources, intellectual property rights, and facilities and equipment) which are mainly based on exploitation or exploration activities. A typology of firms was created, highlighting the large number of firms with no interactions, and six clusters that specialize in specific mechanisms (IPR exploiters, Institutionalized interactors, University facility users, Training and education beneficiaries, Tacit knowledge users, and R\&D interactors). The study also presents the determinants for engaging in each type of channel, concluding that whilst firms developing exploitation activities also develop parallel exploration activities, the reverse is not significant. The absorptive capacity of firms is important in determining the type of interaction, but is not fully conclusive about the range of exploration and exploitation activities. The article ends by discussing the policy implications associated with incentives to adapt knowledge transfer mechanisms to the industrial fabric of peripheral innovation systems.
\end{abstract}

@ 2015 Elsevier Inc. All rights reserved.

\section{Introduction}

Peripheral innovation systems ${ }^{1}$ have greater difficulty in transforming R\&D and higher education endeavours into economic benefits. Even though this problem is not uncommon in many innovation systems, less developed regions and countries fall behind both in terms of business innovation and absorptive capacity (Cooke and Piccaluga, 2004). Their industrial structure is often concentrated in low or medium-technology sectors and services. Low and medium-technology industries play a relevant role in innovation, particularly in terms of employment and production (Hirsch-Kreinsen, 2008). Consisting mainly of small firms and with few large technology users in the local markets, R\&D investment in these systems is dominated by the public sector. The research personnel and scientific facilities are also concentrated in the public sector,

\footnotetext{
* Corresponding author at: Faculty of Economics, University of Algarve, Campus de Gambelas - Edifício 9, 8005-139 Faro, Portugal.

E-mail addresses: mfernandez@iesa.csic.es (M. Fernández-Esquinas), hpinto@ces.uc.pt (H. Pinto), mpyruela@iesa.csic.es (M.P. Yruela), tsp@ces.uc.pt (T.S. Pereira).

${ }^{1}$ In this article the notion of peripheral region is related to the absence of industrial agglomeration, implying the existence of an industrial fabric composed of many SMEs with low absorptive capacity.
}

especially in universities. Although it is more acute in peripheral systems, this difficulty in translating scientific results into the market in the form of innovation is well recognised in the European context, leading some to consider it a European paradox (although the extent to which this difficulty is linked to leadership in science, thus creating the so-called paradox, is disputed; cf. Dosi et al., 2006). As a result, governments are rethinking how to maximize benefits from higher education and public research organisations for skills and development (OECD, 2007).

In the innovation systems which are lagging behind, it is particularly important to understand how universities can contribute more effectively to the innovation process in firms. It is also important to establish evidence to support appropriate knowledge transfer policies. A body of literature has emerged on the factors and motivations that lead firms to draw on knowledge from external sources. Several studies have addressed the propensity of firms to establish links with universities and how such links are related to innovation (Belderbos et al., 2004; Laursen and Salter, 2004; Mora-Valentín et al., 2004). Although it is important to note that universities are ranked low as a source of innovation in comparison with other actors, such as suppliers and business partners (Perkmann et al., 2013), it has been found that knowledge transfers from regional universities may enhance the capacity to 
innovate (Cohen et al., 2002; Uyarra, 2010; Larsen, 2011). Some studies have explored the influence of structural and behavioural factors on the probability of firms seeking out and applying knowledge from universities (Carayol, 2003; Arundel and Geuna, 2004), although, in general, they fail to differentiate between types of knowledge flows and consider university-industry interactions as a homogeneous whole (Jaffe, 1989; Laursen and Salter, 2004).

Another body of literature has dealt with the nature and mix of links through which collaboration takes place (Gulbrandsen et al., 2011). In comparison with the general motives and barriers to university-industry collaboration, forms of engagement have been investigated to a lesser extent. These studies show that knowledge transfer occurs through different channels, pathways or mechanisms (Schartinger et al., 2002; Bekkers and Freitas, 2008) which differ in terms of the level of formality and capacity to transmit codified or tacit knowledge (Bruneel et al., 2010). Nevertheless, much of the attention has focussed on describing channels and exploring conditioning factors. One gap in this field is the fact that there are few studies on the recombination of specific forms of collaboration by firms with different profiles, despite the acknowledgement that mechanisms should not be studied or promoted in isolation (D'Este and Patel, 2007; Perkmann and Walsh, 2007). Technological cooperation and other types of research links are beginning to be studied as "alliance portfolios", as firms combine strategically different but often complementary horizontal and vertical types of mechanisms to broaden their pool of competitive opportunities (Duysters and Lokshin, 2007). Focussing on comparing discrete channels may thus be misleading, as collaboration may entail the use of several channels simultaneously (Levy et al., 2009). The recombination of different channels may provide useful insights into specific forms of knowledge transfer. Nevertheless, it is difficult to systematically observe all the forms of relationships and, at the same time, study the impact of firms' characteristics on their inclination to collaborate.

This article contributes to studies on knowledge transfer between universities and firms by analysing the mix of transfer mechanisms in a peripheral innovation system. By observing the role of specific channels used by firms when collaborating with universities, the study creates a typology of firms according to the combination of channels, and explores the characteristics that shape specific modes of knowledge transfer. The study is based on a survey of 737 innovative firms in Andalusia, a Spanish region with an extensive public higher education sector and a diversified industrial fabric characterized by a predominance of SMEs, an important service sector and a low and medium-tech manufacturing presence. A questionnaire, administered in 2009 to a sample of firms reflecting the variety of sectors, size and innovative profiles in the region, contains a set of questions that deal with various forms of interaction with universities, thus addressing the research gap identified above.

The article is organised into five sections. Following this introduction, Section 2 presents the theoretical and empirical background. Section 3 sets out the study's strategy and presents the hypotheses on the combination of different knowledge transfer channels between universities and industry. Section 4 describes the data source, fieldwork, sample characteristics, and variables used in the survey. The results are presented in Section 5. Using a descriptive analysis, the study follows three analytical steps. Firstly, a factor analysis is developed to identify the patterns underlying the variety of relations. Secondly, a typology of firms is proposed through cluster analysis. Thirdly, the profile of each cluster is analysed through an econometric estimation of the determinants of the channels used by firms. The conclusions section highlights the implications for the literature on industry-university interactions and presents policy options for peripheral innovation systems.

\section{Theoretical and empirical background}

Universities have often been described as "the driving force behind growth", as they generate educational capacities, skills and knowledge that are central to innovation, particularly in certain industrial sectors
(Mansfield, 1998). Comparative studies have highlighted the relationship between industrial investment in $\mathrm{R} \& \mathrm{D}$, innovation and university-industry collaboration, with micro-level research finding that university-industry collaboration is central to this process (Fritsch and Schwirten, 1999; Lööf and Heshmati, 2002; Belderbos et al., 2004). Governments and research agencies have been supporting the development of university-industry relationships, with the aim of promoting the economic impact of university research (OECD, 2002; Mowery and Sampat, 2005).

Nonetheless, two important issues need to be taken into account: a) the impact of these interactions on economic development occurs through specific mechanisms, b) the propensity of firms to engage with universities depends largely on the composition of the surrounding industrial fabric. These are key points in the development of evidence-based innovation policies adapted to their specific contexts.

\subsection{The diversity of university-industry relationships}

Knowledge is embedded in different forms and circulates through multiple channels. Codified academic science is not easily transferred to other non-academic organisations (Pavitt, 2001). Many of the economic benefits of academic research are indirect rather than direct outputs of research, and are often unequally distributed amongst firms. The effects are not linear, but are often based on iterative processes within different types of mutually reinforcing relations, through the circulation of people, instruments and problems where tacit knowledge is of particular importance, in addition to formal knowledge (Salter and Martin, 2001). In this context some firms may find in local universities offer easier access to the pool of knowledge accumulated by academia due to their proximity and flourishing personal relationships (D'Este and Iammarino, 2010). As such, whereas public policies often focus on formal processes, relations between universities and firms are often informal and linked to personal interactions (Perkmann and Walsh, 2007). They emerge from common and overlapping interests and frequently develop through informally negotiated exchanges. Some studies reveal that the most science-intensive collaborative relations, such as patent exploitation, cooperative research and the creation of spin-offs, account for only a small share of the process (Agrawal and Henderson, 2002), especially amongst firms working on services and low or medium-tech manufacturing, which are central to peripheral innovation systems. It has been suggested that more open forms of interaction, such as occupational mobility or workshops, are important channels used by some firms (Cohen et al., 2002). Others use universities as providers of technical services or infrastructures in regions where these services are scarce and expensive. Moreover, universities provide the human resources and specialized training required to upgrade the technological capacities of local firms (Hall et al., 2000; Bonnaccorsi and Daraio, 2007).

One useful distinction that has long been made in the literature highlights the difference between "knowledge exploration" and "knowledge exploitation" (March, 1991). The first usually refers to monitoring procedures aimed at detecting useful external knowledge. The second concerns the active use of a more specific knowledge source that can be directly appropriated by a firm. This distinction can be linked to university-company relationships. For instance, patent licensing and participation in spin-offs are more akin to exploitation activities. Personnel flows and subsidised joint R\&D projects are closer to exploration activities, although contract R\&D and collaborative research centres can be used for both purposes. However, both of these scenarios entail different activities. Firms that lack well-defined innovation needs for their production processes, as well as firms with an insufficient capacity to obtain knowledge internally, are usually expected to develop exploration strategies involving links with universities that differ from those occurring in a knowledge exploitation context. It is widely accepted that knowledge exploitation is related to certain firms that have the ability to understand and recombine knowledge with a high R\&D content. In other words, knowledge exploitation and the generation of new knowledge can operate hand in hand (Zahra and George, 2002). 
In fact, some firms do not invest in R\&D with a view to obtaining direct benefits from it, but to enable them to make use of knowledge that exists in other places (Cohen and Levinthal, 1989; Pavitt, 2001). Thus, it is expected that the most common exploitation activities, such as the use of patents, do not occur independently but are undertaken in conjunction with other activities that strengthen the firm's capacity to adapt IPR to its needs or to take advantage of this relationship for subsequent activities.

One important notion for understanding exploration and exploitation strategies associated with university-industry links is the notion of tacit knowledge adapted to the learning process of organisations. Tacit knowledge usually means the knowledge embodied in the skills and capacities of interlinked groups of people. This knowledge is not easily transmitted without close interaction with people working in organised situations. Tacit knowledge is the opposite of codified knowledge, as exemplified by items of information and techniques that are ready to use (Nonaka and Tagueuchi, 1995). There has been a great deal of discussion about the fact that organisations need to effectively promote the social and cognitive dynamics that enable people to learn the tacit knowledge that is at the core of their productive process (Alegre and Chiva, 2008). This notion has been further extended and applied to innovation systems by examining the knowledge base of productive sectors. In particular, three types of knowledge bases can be distinguished, implying different forms of tacit knowledge: analytical, synthetic and symbolic (Asheim and Gertler, 2005).

An analytical knowledge base is related to a deep understanding of the phenomena usually associated with scientific research. Radically new products and processes are frequently developed in a systematic manner involving mainly basic, but also applied, research. The "science-technology-innovation" (STI) mode clearly predominates in analytical industries. These firms may invest heavily in intramural R\&D, but also rely on knowledge generated in universities and other research organisations. They usually need to understand and use codified knowledge, such us published scientific discoveries and patents with a high R\&D content, although in order to do so their innovation processes also envisage important elements of tacit knowledge.

A synthetic knowledge base is related to the use and new combinations of existing knowledge in order to incorporate elements with functional goals, as is common practice in many manufacturing sectors. Conversely, the process of creating knowledge is inductive and is associated with engineering and learning by doing. Finally, a symbolic knowledge base is present in the creative and cultural industries and is related to the creation of realities with cultural meaning. Innovation focuses on the creation of intangible dimensions, such as aesthetic value and images. Symbolic knowledge is highly context specific: the meaning and the value associated with it can vary considerably in different places. Both the synthetic and the symbolic sectors rely more on the "doing-using-interacting" (DUI) mode of innovation (for a detailed discussion of the STI and DUI modes of innovation, see Lorenz and Lundvall, 2006). They also share deeper components of tacit knowledge. More often than not, innovation occurs through close interaction, trial and error, and the exchange of a variety of skills and experiences in the workplace.

The importance of knowledge transfer channels with universities varies according to the predominant knowledge base in a given industrial sector. Some sectors which have an analytical knowledge base (biomedicine, pharmacy, microelectronics) frequently engage in scientific knowledge production with university researchers, resulting in codified R\&D results such as patents. Other sectors with a synthetic knowledge base (agro-food, the automotive industry, metal industry, low and medium technology manufacturing) mainly require modes of transfer based on the synthesis and recombination of various forms of knowledge. University and industry links may also be relevant, but occur mostly through technical services, training, and staff flows, and less in basic research. Examples include consulting, applied research, some types of analysis, and access to special instruments. Moreover, many manufacturing and services firms with a symbolic knowledge base work in certain sectors (advertising, fashion, tourism, audiovisual content and other cultural products) in which design, image and understanding of the environment's cultural signifiers are important. They require specific channels of knowledge transfer that may be found in universities, such as cultural consultancy work and expertise, to gauge a product's social impact.

The above distinction is particularly important for interpreting the combination of exploitation and exploration dynamics. Links between firms developing both strategies and public research organisations are pivotal and occur more frequently than in other industries. Firms in science-intensive sectors employ learning processes both in order to seek out future exploitation and to understand the functioning of the complex issues behind a particular area of technological expertise (Gulbrandsen et al., 2011). This is an additional explanation for why some high-tech firms also develop exploration activities through university-industry links, aiming to facilitate the transmission of knowledge through collaborative projects, exchanges of personnel, participation in collaborative centres and a variety of informal contacts.

\subsection{Factors influencing university-industry relationships}

The conditioning factors highlighted by empirical research may operate in different ways when specific flows of knowledge transfer are taken into account. From the firms' perspective, three groups of influences are usually considered. The first group concerns the so-called structural elements of a firm, such as its size, age and sector of activity. Start-up firms have been associated with serving as a vehicle for commercializing academic research (Cohen et al., 2002), although other studies have not confirmed this pattern, suggesting that these findings are specific to particular groups of firms, such as spin-offs or those related to science sectors (Laursen and Salter, 2004). Small firms in other sectors may need other interaction channels, such as consultancy and specialized training (Mangematin and Nesta, 1999; Tether and Tajar, 2008). In relation to size, it is often assumed that larger firms have more resources to exploit external sources and manage interactions more effectively (Mohnen and Hoareau, 2003). The strongest links with universities are usually found in large firms and in those operating in technology-intensive sectors such as health, life sciences, ICTs or electronics (Arundel and Geuna, 2004). Some larger firms may prefer stable forms of collaboration in specialized organisations, such as cooperative research centres, whilst others may prefer temporary contract R\&D (Turpin and Fernández-Esquinas, 2011; Canton et al., 2005).

The absorptive capacity of firms has been found to influence these patterns. Absorptive capacity is the “(...) firm's ability to identify, assimilate, and exploit knowledge from the environment" and is dependent on internal investment in knowledge (Cohen and Levinthal, 1989: 569). Investment in internal R\&D activities broadens the firm's knowledge base, thus improving its absorptive capacity by reducing the cognitive distance between other fields or actors, such as universities working in advanced fields. Possessing an R\&D department is one factor that facilitates the organisational capacity to interact and use external knowledge, and is therefore considered a determinant of university-industry interactions (Fontana et al., 2006). Such firms usually employ qualified staff with higher education degrees who are able to recognise the importance of processes that facilitate innovation, reflecting the importance of an optimal cognitive distance for the improvement of absorptive capacity (Nooteboom et al., 2007). Firms with an R\&D department and qualified workers may thus engage more easily in collaborative research, whereas those lacking this organisational structure may need to concentrate on other forms of collaboration through contract research and consultancy.

The industrial fabric is another important factor. Sectors with a high level of investment in R\&D are associated with a higher absorptive capacity, and usually have a higher propensity to draw on knowledge produced in other areas, including universities (Cohen and Levinthal, 
1990). Sector specific dynamics also influence the type of relations. Intellectual property rights (IPR) are usually more important in the pharmaceutical and biotechnology industries than in other sectors (Mansfield, 1995). High-tech companies tend to use channels that allow the transfer of both codified and tacit knowledge, such as research contracts, whilst low-tech companies tend to rely on some forms of personnel relationships, consultancy and the use of equipment (Arundel and Geuna, 2004). Service firms may reveal a distinctive pattern, using universities as providers of technological solutions, although interaction channels in the service sectors are less well studied (Tether and Tajar, 2008).

A second group of factors points to the importance of a firm's strategic search. Some studies suggest that the most dynamic enterprises are those with management schemes that facilitate the development of open innovation and the use of external sources of knowledge (Chiesa and Manzini, 1998; Cyert and Goodman, 1997). According to this perspective, firms that introduce organisational routines aimed at capturing new knowledge through alliances with other organisations will also be more open to collaboration, using universities as a source of strategic information and, on occasion, as places for outsourcing R\&D activities (Chesborough, 2003). However, other firms with less evident open strategies may concentrate their relationships with universities on the sporadic use of equipment and services. The use of patents and other IPR mechanisms (Laursen and Salter, 2014), the demand for knowledgeintensive business services (KIBS) (Miles et al., 1995) or the active use of public programmes to support innovation (Falk, 2007) are signs of a company's focus on knowledge use in its productive processes.

A third group of factors affecting links with universities is related to the opportunities available to firms for establishing relations with the academic sector. These may be called "situational factors" since they are associated with the social and economic structure in which the firm is located. Networks and trust between agents from different sectors (Powell et al., 1996) are important factors that influence university-industry links (Zucker et al., 1998). Geographical proximity has been found to play an important role in knowledge acquisition from other sources (Davenport, 2005) and for integrating academic resources and local capacities (Asheim and Isaksen, 2002). For example, locating firms close to organisations that promote interaction, such as technology parks, may facilitate stronger links between actors and the transfer of tacit knowledge (Löfsten and Lindelöf, 2002), although the empirical research is inconclusive and other studies draw different conclusions (Beise and Stahl, 1999; Mora-Valentín et al., 2004). Nevertheless, proximity transcends geographical scope. As stated by Boschma (2005), spatial distance is relevant to innovation, but organisational, cognitive and institutional proximities are also crucial to cooperation and connectedness amongst innovation actors and the effectiveness of knowledge flows.

\section{Strategy of the study}

\subsection{Methodological clarifications}

Empirically determining how firms obtain competitive advantages by collaborating with universities is a difficult task. Firstly, it is costly to obtain data sources that can simultaneously capture structural, strategic and situational factors, especially for SMEs in the low-tech and service sectors in peripheral regions, thus making it difficult to compare the factors that aid or prevent firms with different profiles from establishing links with universities. Much of the empirical research specifically designed to study this issue tends to focus on industrial sectors that are closely linked to research, such as biotechnology (Hicks et al., 2001; Owen-Smith and Powell, 2004). Numerous studies are based on firms with particular characteristics, normally firms with R\&D departments (Autio et al., 1996; Cohen et al., 2002), start-ups related to high-tech production processes and, in some cases, spin-offs emerging from a small number of universities with high research profiles (Shane,
2002). These studies have proved inconclusive when examined outside the intensive-knowledge environments in which such firms usually operate. The results are difficult to extrapolate to the small and mediumsized innovative firms that are commonplace in most of the peripheral regions.

Secondly, there are methodological limitations involved in specifying the type of relationships that actually exist between the different industrial sectors and universities according to specific regional environments. Studies that examine a wider variety of firms normally use data sources that are not designed for the study of university-industry relationships. Many of these empirical analyses are based on official innovation surveys such as the Community Innovation Survey - CIS. Although the CIS uses large samples covering a full range of firms, the questionnaire is not usually designed to gather detailed information on the forms of knowledge transfer of the firms involved. Given that it is not the main goal of these surveys to examine this particular type of business behaviour, the analyses are based on "proxy" variables that do not reflect the range and the intensity of such links (Mohnen and Hoareau, 2003). Thus, although these studies are central to our current understanding of innovation processes and firms' access to external knowledge, their policy implications are not necessarily clear, given the diverse situations in which university-industry interactions occur.

Other limitations arise from a diversity of operational procedures, both in terms of measurement instruments and fieldwork. On the one hand, studies based on general innovation surveys provide results that may differ from studies specifically designed to observe universityindustry links. When firms are asked about their interactions with universities, they may identify certain activities which would not otherwise be considered in general innovation surveys. On the other hand, studies designed specifically to analyse these interactions use particular indicators focusing on the different forms of knowledge transfer. Some of these may include a detailed account of interactions, whilst others include items encompassing several possibilities. Some of the questions use frequencies, whilst others use ordinal scales (see, for instance, the account produced by Gulbrandsen et al., 2011, and Perkmann and Walsh, 2007). Regarding fieldwork, whilst online surveys can usually only include simple questions with limited dimensions, face-to-face interviews offer a wider range of possibilities. In short, the specialist literature on this topic underlines the need for specific and homogeneous indicators that are capable of measuring the wide range of possible relationships, together with fieldwork procedures that are able to capture the underlying diversity (Lepori et al., 2008).

\subsection{The region}

Andalusia is a region located in southern Spain. With a population of almost 9 million inhabitants and an area of $87,000 \mathrm{~km}^{2}$, it is geographically diverse with large rural enclaves and several metropolitan areas. Traditionally, Andalusia has been considered a less-developed territory but has experienced a process of rapid change and is now practically on a par with the Spanish national average in several socio-economic indicators. Nevertheless, the region continues to lag behind most other regions in Spain in terms of its economic development - 74.1\% of the GDP per capita of Spain in 2014 (INE data from Regional Spanish Accounts). Family-owned SMEs account for a large proportion of firms, with most operating traditional service sectors related to personal services, such as tourism. The industrial sectors are largely oriented towards local markets and dedicated to low knowledge-intensive activities, in a region where only $33 \%$ of the R\&D expenditure is accounted for by the business sector (INE, 2010). The existing large manufacturing firms are usually the result of delocalization processes implemented by multinational firms during the 1970s and 1980s, meaning that the R\&D labs of these firms have remained outside the region. Despite this broadly uniform picture, regional firms are becoming increasingly heterogeneous as a result of regional strategies, often supported by national and European policies for the creation and 
diversification of businesses. The traditional agro-food sector, for instance, is becoming more heterogeneous and knowledge intensive, whilst other important new developments have also emerged in the area of renewable energies, aerospace and tourism, as well as in related knowledge-intensive business services (Junta De Andalucía, 2003; INE, 2010).

The university sector is managed and funded by the Regional Government. Andalusia currently has nine public universities with some 250,000 students and 17,000 teaching and research staff (FernándezEsquinas et al., 2008). The growth of the university system since the 1970s was largely a response to training needs in the region (the upper level of vocational training is included in the university system), leading to an organisational model traditionally centred on teaching. Investment in the development of scientific capacity in recent years has led to the concentration of a large part of the regional R\&D resources in universities. Universities account for $45 \%$ of $R \& D$ expenditure, and $61 \%$ of researchers in the region are employed by universities. Despite the large university system, it is not possible to clearly classify universities according to their scientific quality or in terms of research or teaching orientation. All the universities are located in urban areas, with one university in each provincial capital and two in Seville. All of them provide several degrees in a variety of fields, from the so-called 'technical degrees' (close to the upper level of vocational training) to doctoral degrees. Given the diverse internal composition of universities, classifications in terms of productivity are not meaningful within the regional system. ${ }^{2}$

In this context Andalusia has seen important changes in recent years as a result of the reorganisation of R\&D and higher education policy in 2003, with the aim of improving university support for innovation processes in firms. Andalusia is a good example of the rapid transition from traditional policies based on a linear model of innovation to policies aimed at interaction between the public administration, the educational system and industry (CICE, 2006). One relevant example of the more interactive polices is the network of offices that has been established to provide support for knowledge transfer and innovation, thus facilitating company interactions with different agents in the region.

\subsection{Data source}

This study uses a directory of firms produced by the regional government network of offices that provides an assessment of innovation. ${ }^{3}$ The data set was developed to identify firms in the region in order to develop measures to improve their involvement in networks with other firms and in regional innovation programmes. The directory contains data on 1,898 firms that have received some form of public financial support for innovation from regional, national or European sources during the period 2000-2008. In addition, the network has added firms considered to have an interest in innovation because of the activities they develop or the positive feedback they provide when contacted by local offices.

This data source has advantages and drawbacks in terms of the dilemma between "representativeness" and "specificity" that often arises in innovation studies. One limitation is that the data is biased with respect to the entire population of firms in the region, although this was not expected to significantly affect our focus on firms interacting with universities. ${ }^{4}$ The main reason for choosing the data

\footnotetext{
2 Public Research Institutes are not central actors in the system. They account for less than $10 \%$ of the R\&D expenditure and employ around 1500 staff. These consist mainly of CSIC institutes (Spanish Council for Scientific Research, the public network of research centres managed by the central state), hospital units and agricultural research institutes managed by the regional government (INE, 2010).

3 The database was provided by the RETA network (Red de Espacios Tecnológicos de Andalucía) and CIT ANDALUCIA [www.reta.es].

${ }^{4}$ It should be noted that the bias is unidirectional. The majority of very small firms in the region that operate in very low-level technology sectors are not represented. However, practically all the technology-intensive firms, as well as those engaged in significant R\&D activities - including both small and large companies - have received some form of public aid, at least through tax deductions. For this reason they are included in the data file that is used as a source.
}

set is its strategic value for analysis. The alternative option of choosing a random sample of firms in the region would lead to the inclusion of only a very small percentage of firms with any university interaction, leading to a situation similar to that found in official innovation surveys, which we aimed to overcome. ${ }^{5}$ As such, this data source is considered an operational population that fits the goals of our study, reflecting the expected heterogeneity. Firstly, it contains firms with varying innovation capacities that have obtained different types of financial support, including firms that have received non-R\&D related aid for innovation (e.g. a computer network or a web marketing system) as well those engaged in highly scientific activities (e.g. R\&D projects developed by aeronautical firms). Although some of them have a dedicated R\&D department, most do not. Secondly, it includes a wide range of business activities and sizes of firm, ranging from SMEs to large companies. Thirdly, the firms surveyed are not only located in industrial areas or in technology parks near universities, but are dispersed geographically throughout the urban and rural areas of Andalusia.

\subsection{Sample, fieldwork and indicator set}

A sample of 800 enterprises was created by random selection, with a proportional distribution between strata formed by the sector of activity and the province where the firm was located. The fieldwork was conducted by means of personal interviews which took place on the firms' premises in the following sequence. The firms selected in the sample were contacted, first by post and later by telephone, to ask if they would take part in the study. Each firm had been researched in advance in order to choose the appropriate person to respond to the questionnaire. ${ }^{6}$ An appointment was then arranged and a professional survey taker travelled to the firm's offices to conduct the survey.

In the case of firms that refused to answer the survey, a randomly selected replacement sample was used following the same criteria. The acceptance rate in the first phase was $76 \%$ and in the second phase $72 \%$. A total sample of 737 firms was obtained. The main characteristics of the firms included in the sample can be found in the Total column of Table 6 . The firms are predominantly independent, with less than one quarter belonging to a business group. The number of employees reflects the size of enterprises in the region: $52 \%$ employ ten workers or less, whilst only $14 \%$ have more than 50 workers. A large number of the firms can be considered young: 18\% were created after 2000 . Their geographical location varies throughout the region, as does their sector of activity. With regard to innovation capacity, $21.3 \%$ have an $R \& D$ department on the premises and 3.8\% have off-site R\&D departments.

The information collected was grouped into four main categories: a) characteristics of the firm, b) innovation capacity and innovation activities, c) links with the university sector, d) geographical location and company relationships. In the survey particular importance was given to section c). Decisions regarding survey design were inspired by previous studies, as well as the report on third-stream indicators by Molas-Gallart et al. (2002). However, the indicators were adapted to the context of the region in which the firms are located. The indicator set was developed using an activity-based approach. The survey focused on the type of the interactions that took place between firms and universities, rather than the economic impact of these interactions. Several pre-tests were carried out in order to classify a large list of activities into

\footnotetext{
${ }^{5}$ In the national innovation survey, $8 \%$ of the innovative enterprises surveyed stated that they had collaborated in some way in R\&D activities with a university or a public research centre in 2005 (PITEC, 2005).

6 Each firm was allowed to select the most appropriate person to answer the questionnaire, although the choices were restricted to the following positions: the owner of the firm, the executive director, the head of the R\&D or innovation department, or the person in charge of the department most closely related to innovation strategy.
} 
a set that included meaningful options for the company respondents. The final set of indicators includes twelve possibilities for interaction, ranging from R\&D contracts and consultancy to training and staff mobility, as well as commercialization of IPR-related activities (List 1, appended). For each of these items the respondent was asked whether the firm had engaged in such activities during the previous five years and the number of times this had occurred.

\subsection{Aim and hypotheses of the empirical study}

The goal of the study was to analyse the interactions between various types of firms and universities in peripheral regions and to examine the factors that shape the different combinations of relationships. It order to do so, an exploratory strategy was used, based on empirical observations designed to provide a detailed account of company behaviour. The study used multivariate procedures to find the latent dimensions of university-industry interactions (through factor analysis) and a typology of innovative firms (cluster analysis). An econometric analysis was then developed to identify the determinants of each type of interaction mechanism.

These methodological choices are theoretically grounded in assumptions from this field of research. Firstly, it is necessary to construct an appropriate data source, both in terms of the characteristics of the firms (a variety should be included, rather than science-related firms only) and the indicators that reflect their modes of interaction with universities (a wide range of links should be covered). In addition to studies on company behaviour, a productive line of research for empirical purposes emerges from studies on the so-called "third mission" activities. This perspective focuses on the university sector, although it contains proposals for indicators that are useful in determining the dimensions that should be considered when studying university-industry links. It considers commercial indicators to be insufficient for measuring the broader spectrum of potentially productive activities (Gulbrandsen and Slipersaeter, 2007), highlighting the need to observe industry behaviour beyond motivations based on obtaining immediate economic benefits. These indicator schemes take different possibilities for interaction into account, notably the use of IPR, contract research, consultancy services, transfers through education and human resources development, and dissemination, as well as the use of facilities and scientific instrumentation (Molas-Gallart et al., 2002).

Secondly, it is necessary to depart from a detailed map of different business practices. For this purpose, although exploratory analyses were used, the approach is intended to be used as a theory-building exercise based on the assumptions underlined in the literature. Given that one main goal of this article concerns the way in which relationships are structured, out strategy initially explores interaction patterns and establishes assumptions about the expected features of firms in each typical mode of knowledge transfer. Subsequently, the analysis identifies the traits of the firms, interpreted as independent variables that may have an impact on the firm's behaviour.

The following hypotheses address the distribution of the combination of links with universities across different types of firms. The background assumption is that in a diversified business environment the mix of interactions reflects the company profiles (Jensen et al., 2007). At one end of the scale there will be many firms with a low absorptive capacity, for whom interaction with universities is unlikely. At the opposite end, firms with a higher absorptive capacity will establish stronger links in many dimensions. Both situations, however, encompass a complex range of possibilities in which the various interactions may be shaped by factors associated with a company's structure, strategy or situation. It is expected that some groups of firms will concentrate on exploration (Perkmann et al., 2013). On the other hand, when mixing different channels of knowledge transfer, companies that focus on knowledge exploitation will normally pursue this aim together with other activities. Firms that seek to exploit external knowledge will also benefit from some degree of exploration in order to acquire strategic information and skills (Strambach and Klement, 2012). Therefore, it is expected that few firms will concentrate only on exploitation activities. These dynamics led to the following hypothesis:

H1. Firms can be distinguished according to whether they use exploration activities only or supplement exploration with exploitation.

Firms with a high capacity for exploiting patents through licenses will normally take part in other activities in cooperation with universities. These will be combined with other R\&D activities aimed at exploration (e.g. R\&D projects), namely activities that facilitate the transfer of tacit knowledge (e.g. research training and human resources exchange). It is expected that most of these firms will have qualified personnel and an R\&D department and be operating in science-intensive sectors (Larsen, 2011). However, the majority of potentially innovative firms in peripheral innovation systems have a limited absorptive capacity. Firms that use exploration procedures other than R\&D chiefly focus on tacit knowledge. Hence, in these cases, the channel for interaction with universities is more closely linked to the skills and capacities of university personnel, establishing relationships based mainly on human resources training and exchanges (Tether and Tajar, 2008). It is expected that firms with a lower absorptive capacity, especially in the service sector, will focus on this form of interaction. Conversely, it is expected that more knowledge-intensive firms will be able to develop different types of interactions. This leads to the following hypothesis:

H2. Firms with a higher absorptive capacity combine exploration and exploitation activities.

Additionally, in an attempt to improve interim elements of their production process, some firms may take advantage of the instruments, facilities and consultancy work that universities offer. This is often the case with firms in specific industrial sectors that find in universities offer a service that is difficult to obtain in an environment with few knowledge-intensive business services (Grillitsch and Trippl, 2014). Moreover, it may be costly to resort to such services if they are located elsewhere. These activities are not necessarily associated with other R\&D-based activities or human resources. Many firms will maintain links for the specific purpose of using the equipment provided by the universities in their immediate area, focusing on these services (Pinto et al., 2013). In these instances, they will also take advantage of the expert advice provided by local university staff. Access to these kinds of services is facilitated by proximity, both in terms of cost and more substantial social relationships (Davenport, 2005), leading to the development of the following hypothesis:

H3. Physical proximity to a university is a catalyst for university-industry interactions.

\section{Results}

\subsection{Descriptive results}

Table 1 shows company interactions with universities. It should be noted that informal relationships obtain the highest value (32\% of the firms stated that they engaged in this type of interaction), followed by the training of university personnel inside the firm (27.5\%). The latter is especially significant due to regional government programmes which promote the training of university postgraduates in firms (CICE, 2006). Moreover, it is a common mechanism for identifying future employees and lowering the risks involved in recruiting staff.

The rest of the interactions can be divided into three groups: firms that engage in consultancy, joint research projects and university training programmes for their employees (15\%-25\%); firms that contract R\&D projects, lease or use university facilities and engage in the exchange of personnel (5\%-15\%); firms that have participated in the creation of spin-offs or start-ups, the sale or transfer of patents and 
Table 1

Types of interactions with universities.

\begin{tabular}{|c|c|c|c|c|c|c|c|c|}
\hline & \multirow{2}{*}{$\begin{array}{l}\text { \% answering "yes" to each } \\
\text { type of interaction }\end{array}$} & \multirow{2}{*}{$\begin{array}{l}\% \text { do not know/no } \\
\text { answer }\end{array}$} & \multicolumn{6}{|c|}{ Collaborative intensity (number of interactions) } \\
\hline & & & $\overline{\mathrm{N}^{\mathrm{a}}}$ & Max & Mean $^{\mathrm{a}}$ & $\begin{array}{l}\text { Std. } \\
\text { deviation }^{\mathrm{a}}\end{array}$ & Mean $^{\mathrm{b}}$ & $\begin{array}{l}\text { Std. } \\
\text { deviation }^{\mathrm{b}}\end{array}$ \\
\hline Consultancy work & $21.8 \%$ & $0.1 \%$ & 124 & 80 & 7.1 & 11.0 & 1.3 & 5.4 \\
\hline $\mathrm{R} \& \mathrm{D}$ projects commissioned from universities & $14.0 \%$ & $0.0 \%$ & 87 & 20 & 3.6 & 3.5 & 0.4 & 1.7 \\
\hline Joint R\&D projects & $22.1 \%$ & $0.0 \%$ & 145 & 33 & 3.8 & 4.8 & 0.8 & 2.6 \\
\hline Use or rental of facilities & $8.1 \%$ & $0.1 \%$ & 48 & 48 & 4.6 & 7.3 & 0.3 & 2.2 \\
\hline Patent exploitation & $4.6 \%$ & $0.5 \%$ & 28 & 8 & 2.5 & 2.5 & 0.1 & 0.7 \\
\hline In-company training of university postgraduates and internships & $27.5 \%$ & $0.1 \%$ & 158 & 147 & 8.1 & 16.0 & 1.8 & 8.4 \\
\hline Exchanges of personnel & $7.1 \%$ & $0.1 \%$ & 40 & 20 & 4.3 & 4.5 & 0.2 & 1.4 \\
\hline Training of company workers by the university & $15.2 \%$ & $0.5 \%$ & 93 & 40 & 4.1 & 5.0 & 0.5 & 2.3 \\
\hline Joint ventures with universities & $3.7 \%$ & $0.1 \%$ & 22 & 2 & 1.1 & 0.3 & 0.0 & 0.2 \\
\hline Participation in spin-offs and start-ups & $3.9 \%$ & $0.3 \%$ & 27 & 7 & 5.4 & 19.0 & 0.2 & 3.7 \\
\hline Informal networks & $32.2 \%$ & $0.8 \%$ & 147 & 80 & 8.2 & 14.5 & 1.9 & 7.7 \\
\hline Other types of collaborative Activities & $1.9 \%$ & $15.8 \%$ & - & - & - & - & - & - \\
\hline
\end{tabular}

a Base: firms displaying at least one type of interaction.

b Base: total number of firms.

joint ventures (less than $5 \%$ of the sample). Other less frequent modes of interaction such as participation in meetings, seminars, dissemination and publications have been grouped into one category, since less than $2 \%$ of the firms engage in these activities. It should be emphasised that training and personnel exchanges, as well as consultancy work, carry considerable weight, whereas the exploitation of intellectual property rights is less important, even when the sampled firms are regarded as the most innovative in the region.

The results are consistent with other accounts of university-industry links, in particular regarding the importance of contract research and joint R\&D projects (Boucher et al., 2003; García Aracil and Fernández De Lucio, 2008) and personal interactions. Other studies indicate that dissemination and use of IPR play a more important role, reflecting the presence of different industrial structures (Alegre and Chiva, 2008; Azagra-Caro et al., 2010). The specific features of the region are better reflected in the importance placed on training and the use of university facilities and consultancy. In addition, it is important to notice that the results are consistent with observations made from the university perspective in the region of Andalusia, using the same indicator set and similar analytical procedures (Ramos-Vielba and Fernández-Esquinas, 2011). ${ }^{7}$

Finally, 421 firms (57\% of the sample) stated that they did not engage in any form of collaboration, whilst 305 (41\%) stated that they engaged in other forms of collaboration in addition to informal relationships. Only eleven firms stated that they only engaged in informal relationships. This demonstrates that informal relationships are not developed in isolation, but are linked to other types of interaction and the contribution made by this indicator is therefore limited.

\subsection{Latent dimensions of university-industry interactions and types of innovative firms}

This section presents a map of the firms according to the interactions they engage in with universities. Ten variables were analysed, with the exception of informal relations and those included in the miscellaneous category. ${ }^{8}$ Given that the correlations between variables may distort the results of a cluster analysis, a factor analysis was first carried out, the underlying dimensions of which can be used as normalized variables.

Several factor analyses were carried out on the "Yes/No" categories and the frequencies for each type of interaction, although the most

\footnotetext{
${ }^{7}$ As part of the same project, a survey was carried out using university research groups as unit of analysis. The results show similar frequencies and aggregation patterns.

${ }^{8}$ Informal relations have been excluded because they do not reflect a specific form of link since they are developed in parallel with others. The firms that only engaged in informal relationships or other types of unspecified links were included in the group that engages in no type of interaction.
}

significant result was obtained with the first option. Five dimensions were selected. ${ }^{9}$ Table 2 shows the underlying structure of university-industry relationships, identifying the existence of common interaction patterns. In Table 2, interactions related to R\&D projects and consultancy work are grouped together, as are those related to the training and exchange of personnel. This was also the case for participation in the creation of a new enterprise or joint venture, although joint ventures are also associated with the in-company training of university personnel. Finally, there are two clearly separate specific activities: the exploitation of patents and the use of university facilities or equipment.

These five factors were labelled according to the characteristics of the activities they include: F1 - Exploration through generation and adaptation of knowledge activities, F2 - Exploitation through creation of new organisations, F3 - Exploration through training and exchange of human resources, F4 - Exploitation of intellectual property results, F5 - Exploitation of facilities and/or equipment.

The hierarchical cluster analysis undertaken presents six groups of firms that are homogenous in terms of their internal composition. These types of firms are characterized by their engagement in certain cooperative activities rather than others. At one end of the scale, the analysis identified a large cluster of firms that has not engaged in any type of interaction (labelled C0 - Null interactors). ${ }^{10}$ At the opposite end, it identified groups of very active firms which engage in knowledge-intensive activities. Table 3 shows the cluster distribution, whilst Table 4 indicates the type of relationships in which each cluster of firms has been engaged.

Table 5 describes the clusters according to the activities in which they engage and their weighting in the sample, and relates these profiles to the hypotheses presented above.

In order to characterize each cluster, selected variables are classified according to the dimensions labelled above as "structural", "strategic" and "situational" components of the firm (Table 6). The first set concerns the background of the firm, such as its industrial sector (coded following the technology-intensity classification by OECD, 2002), age, number of workers, turnover, market scope (regional, national or

\footnotetext{
9 The factor analysis was conducted using dichotomous variables that indicate whether each type of relationship exists or not, with values of 0 and 1 . The first five factors explain $70 \%$ of the variance. Three of them have eigenvalues higher than 1 , whilst two have eigenvalues above 0.95 . The same procedure of factor analysis followed by cluster analysis was conducted using interval variables referring to the number of contacts in the same given period. These analyses did not produce meaningful results and suggest that the interval measurements for university-industry relationships obtained through questionnaires are not sufficiently valid to create significant groups.

10 This group was not included in the cluster analysis because we wanted to specify its differences to firms with only a few of them. Moreover, in a former analysis including firms with no relationship the results did not provide a meaningful classification of firms with few interactions.
} 
Table 2

Factor analysis of interaction types. Rotated component matrix.

\begin{tabular}{lrrrrr}
\hline & \multicolumn{6}{l}{ Components $^{\mathrm{a}}$} & & & \\
\cline { 2 - 7 } & $\mathrm{F} 1$ & $\mathrm{~F} 2$ & $\mathrm{~F} 3$ & $\mathrm{~F} 4$ & \multicolumn{1}{l}{ F5 } \\
\hline Consultancy work & $\mathbf{0 . 7 6 6}$ & -0.049 & 0.249 & 0.117 & 0.184 \\
R\&D projects commissioned & $\mathbf{0 . 7 8 3}$ & 0.096 & -0.002 & -0.061 & 0.062 \\
$\quad$ from universities & & & & & \\
Joint R\&D projects & $\mathbf{0 . 7 1 5}$ & 0.166 & 0.133 & 0.189 & -0.141 \\
Use or rental of facilities & 0.072 & 0.121 & 0.087 & 0.002 & $\mathbf{0 . 9 3 3}$ \\
Patent exploitation & 0.161 & 0.198 & 0.213 & $\mathbf{0 . 7 2 0}$ & -0.137 \\
In-company training of & -0.037 & 0.284 & $\mathbf{0 . 3 6 5}$ & -0.644 & -0.244 \\
$\quad$ university postgraduates and & & & & & \\
$\quad$ internships & & & & & \\
Exchange of personnel & 0.070 & 0.415 & $\mathbf{0 . 6 0 9}$ & 0.113 & 0.095 \\
Training of company workers by & 0.246 & -0.077 & $\mathbf{0 . 8 3 8}$ & -0.025 & 0.046 \\
$\quad$ the university & & & & & \\
Joint ventures with universities & 0.214 & $\mathbf{0 . 8 3 3}$ & -0.054 & -0.152 & 0.015 \\
Participation in spin-offs and & -0.038 & $\mathbf{0 . 6 2 6}$ & 0.252 & 0.329 & 0.163 \\
$\quad$ start-ups & & & & & \\
\hline
\end{tabular}

Values for each type of interaction: 0 "no interaction", 1 "at least one interaction".

Extraction method: main components analysis. Rotation method: Varimax with Kaiser normalization.

a \% of variance explained: $78.8 \%$.

international) and integration within a corporate business group. Other variables reflect the absorptive capacities of the firm more directly. They include the existence of an in-company R\&D department, the size of the $R \& D$ department and the qualifications of the workers. The innovation performance of the firm is characterized on the basis of two survey questions on whether the firm has launched an innovative product or process on the market in the last five years. ${ }^{11}$

A second set of variables reflect the firm's strategy regarding its openness to external sources. Since this dimension is usually difficult to detect, two compound variables were constructed reflecting the role that different external sources play in the innovation process of the firm. One compound variable is composed of the number of times a firm states that external organisations are 'important' or 'very important' as a source for innovation. This is based on a list of 11 types of organisations, ranging from R\&D-intensive to local organisations (see Table I, appended). The other compound variable is based on the number of times a firm states that a knowledge-intensive business service (KIBS) is considered important or very important as a source for innovation. For this variable, a list of eleven KIBS was used. Both compound variables show internal consistency (Cronbach alpha $=0.61$ and 0.69 ) and both reflect the extent to which the firm will be interested in an open innovation strategy.

A third set of variables reflects the situational attributes of the geographical environment in which the firm is located and its links with other organisations. In the case of the former, a classification of the type of location is used, distinguishing between technology parks, industrial, urban and rural areas. As a measure of proximity, a variable indicates whether the university with which the main activities have been developed is located in the same province as the firm. ${ }^{12}$ The latter is based on the firm's membership of several types of association. These links can be interpreted as a reflection of the firm's social capital.

By cross-tabulating the three sets of variables, the basic characteristics of each cluster are obtained. The rows in Table 6 present the categories of variables. The columns for each cluster show the percentage of firms in each value (for nominal and ordinal variables) or the mean

\footnotetext{
11 The measurement of innovation performance is a limitation in the study because the questionnaire could not include a detailed account of the processes, or the failure or success in introducing innovations.

12 The questionnaire asked the firm to select the location of the university with which the main activities are developed. The options are "in the same province", "in the region", "outside the region". This classification is more meaningful than distance in kilometres because all universities are located in provincial capitals. The easiest connections are usually to the provincial capital.
}

Table 3

Distribution of clusters.

\begin{tabular}{lrrr}
\hline & N & \% collaborative firms & \% total \\
\hline C0 - Null interactors & 432 & & 58.6 \\
C1 - IPR exploiters & 53 & 17.4 & 7.2 \\
C2 - Institutionalized interactors & 22 & 7.2 & 3.0 \\
C3 - University facility users & 41 & 13.4 & 5.6 \\
C4 - Training and education beneficiaries & 68 & 22.3 & 9.2 \\
C5 - Tacit knowledge users & 66 & 21.6 & 9.0 \\
C6 - R\&D interactors & 45 & 14.8 & 6.1 \\
Excluded cases & 10 & 3.3 & 1.4 \\
Total & 737 & 100.0 & 100.0 \\
\hline
\end{tabular}

Optimal division of collaborative firms in six clusters according to the following criteria: Schwarz's Bayesian Criterion (BIC minimum) $=834.3$; Ratio of Distance Measures (maximum) $=1.6$.

(for interval variables). Although the aim of the analysis is exploratory, it can provide insights into the factors that influence the different kinds of relationships firms have with universities.

The clusters that are most similar in terms of their collaboration patterns with universities also present some common features related to the kind of firms they include. The ' $\mathrm{C} 1$ - IPR exploiters' and ' $\mathrm{C} 2$ Institutionalized interactors' clusters are the most similar in terms of types of relationships with universities. Compared to the other clusters, they include larger firms, firms that are more directed towards the national and international market rather than the local market, and firms that belong to a corporate group. More than half of the firms in these groups have R\&D departments and a larger number of workers in these departments than firms in other the clusters, as well as more frequent innovation activities, especially in product innovation.

C1 firms engaged in exploiting IPR are younger, smaller and have more workers with higher education degrees than C2 firms engaged in institutional cooperation. C2 firms place less importance on external organisations as sources for innovation than C1 firms, although this does not apply to KIBS. Moreover, they are more likely to be concentrated in certain locations, namely technology parks, and consequently more of them belong to certain types of association, in particular regional technology centres and business associations related to innovation. In short, C2 has some distinctive characteristics in addition to those in C1, reflecting firms with a greater absorptive capacity in terms of innovation activities and internal organisational arrangements for in-house R\&D. The above result reinforces H2. This cluster is characterized by using patents and largely engages in many of the other activities, particularly the exchange and training of personnel and a variety of research projects. It also includes firms with a higher knowledge-intensive profile. Nevertheless, the association between absorptive capacity and the combination of multiple channels can be extended to firms involved in institutional collaboration, although a distinction between both is recommended since C2 firms only develop limited patent exploitation.

'C5 - Tacit knowledge users' and 'C6 - R\&D interactors' show only slight differences in the background of their firms in comparison to C1 and $\mathrm{C} 2$, although there are greater differences in absorptive capacity. C5 includes fewer firms with R\&D departments than C1 and C2, and smaller departments, even though these values are high in comparison to the sample as a whole, and to the other clusters. The number of firms with product and process innovation is also smaller than in the previous clusters. In C5 only slight differences are found in the compound variables for the importance paid to external sources in comparison to C1 and $\mathrm{C} 2$, although the network of relationships is less tight, especially in terms of innovation-related associations. In contrast, C6, which comprises firms engaged in R\&D consultancy work and projects, falls behind quite considerably in terms of workers' qualifications and absorptive capacity. It includes older and smaller firms than the three previous groups. It also has fewer workers with university degrees, fewer firms with R\&D departments, and fewer product innovation activities. More of the firms in this cluster are located in places other than technology parks, and some of them are in rural areas. In short, it may be said that 
Table 4

Types of interactions with universities by firm clusters (\% of firms within the clusters that have a stated relationship with a university).

\begin{tabular}{|c|c|c|c|c|c|c|c|}
\hline & $\begin{array}{l}\mathrm{C} 0-\text { Null } \\
\text { interactors }\end{array}$ & $\begin{array}{l}\text { C1 - IPR } \\
\text { exploiters }\end{array}$ & $\begin{array}{l}\mathrm{C} 2- \\
\text { Institutionalized } \\
\text { interactors }\end{array}$ & $\begin{array}{l}\text { C3 - } \\
\text { University } \\
\text { facility users }\end{array}$ & $\begin{array}{l}\text { C4 - Training and } \\
\text { education } \\
\text { beneficiaries }\end{array}$ & $\begin{array}{l}\text { C5 - Tacit } \\
\text { knowledge } \\
\text { users }\end{array}$ & $\begin{array}{l}\text { C6 }-\mathrm{R} \& \mathrm{D} \\
\text { interactors }\end{array}$ \\
\hline Consultancy work & 0.0 & 67.9 & 72.7 & 63.4 & 7.4 & 74.2 & 48.9 \\
\hline R\&D projects commissioned from universities & 0.0 & 41.5 & 68.2 & 31.7 & 2.9 & 45.5 & 40.0 \\
\hline Joint R\&D projects & 0.0 & 69.8 & 86.4 & 43.9 & 11.8 & 71.2 & 55.6 \\
\hline Use or rental of facilities & 0.0 & 13.2 & 31.8 & 100.0 & 0.0 & 0.0 & 2.2 \\
\hline Patent exploitation & 0.0 & 58.5 & 9.1 & 0.0 & 0.0 & 0.0 & 2.2 \\
\hline $\begin{array}{l}\text { In-company training of university postgraduates and } \\
\text { internships }\end{array}$ & 0.0 & 39.6 & 90.9 & 58.5 & 100.0 & 93.9 & 2.2 \\
\hline Exchange of personnel & 0.0 & 32.1 & 40.9 & 17.1 & 1.5 & 19.7 & 0.0 \\
\hline Training of company workers by the university & 0.0 & 67.9 & 45.5 & 41.5 & 0.0 & 71.2 & 0.0 \\
\hline Joint ventures with universities & 0.0 & 5.7 & 95.5 & 0.0 & 0.0 & 0.0 & 0.0 \\
\hline Participation in spin-offs and start-ups & 0.0 & 30.2 & 31.8 & 12.2 & 1.5 & 0.0 & 0.0 \\
\hline
\end{tabular}

there is a decrease in innovation-related features, firstly between $\mathrm{C} 1$ and $\mathrm{C} 2$, and then between $\mathrm{C} 5$ and $\mathrm{C} 6$. The above groups do not provide clear implications for the profile of firms described in H1. It is difficult to find a specific type of firm that is oriented towards exploration or exploitation. Both options may include activities with different scientific content that should be differentiated.

Different kinds of firms are found in ' $\mathrm{C} 3$ - University facilities users' and ' $\mathrm{C} 4$ - Training and education beneficiaries'. C3 includes larger firms, mostly in the area of technical and professional services. It also has more firms in which a substantial number of workers have university degrees, as well as those which have an R\&D department. However, C3 includes fewer firms with product or process innovation and few differences can be found in their strategy for open innovation. The main feature in the situational variables is that a quarter of these firms are located in technology parks (ranking second for this feature after C2), and a larger share of them belong to associations oriented towards innovation. The C4 firms, on the other hand, are smaller and older, more oriented towards the regional market, and hardly any of their employees have PhDs. Few of them have R\&D departments or engage in product or process innovation. Moreover, only a few are located in technology parks, and most of their relationships are with local or sector-based associations. These results help to evaluate the expected profile of firms associated with forms of knowledge transfer that concentrates on training as opposed to the use of university facilities. Some firms which use universities for training purposes have a lower absorptive capacity and are concentrated in certain manufacturing sectors. However, others which use human resources training present a different profile. Only firms working in technical and professional services (related to the so-called KIBS) have a greater presence in the cluster that uses university facilities, whilst firms in the manufacturing sectors do not present a specific pattern.

Finally, the 'CO - Null interactors' cluster encompasses firms that have important differences in comparison to the rest of the clusters, especially those involved in more intensive cooperation. It includes smaller, independent, locally oriented firms. They are less innovative, have few workers with higher education degrees, and few of them have R\&D departments. They also ascribe less importance to external organisations and services. Their links are concentrated more on local or sectorial associations. Although a few of them are located in technology parks, there is no clear pattern for geographical distribution in comparison to the other clusters, since most of the firms in $\mathrm{CO}$ are located in industrial districts and central urban areas.

Table 5

Typology of firms interacting with universities.

C1 - IPR exploiters: This group is mainly characterized by the exploitation of patents and other forms of IPR ( $58.5 \%$ of the firms have engaged in this type of activity). Compared to the other groups, it includes firms which have been involved in the creation of a new firm (30.2\%), although it also shows high scores for receiving specialized training from universities, as well as for the exchange of personnel, consultancy and participation in R\&D projects. It comprises 53 cases, accounting for $7.2 \%$ of the sample. This group contributes towards confirming $\mathrm{H} 2$ and indicates that exploitation of IPR requires specialized knowledge that is facilitated by the other channels.

C2 - Institutionalized interactors: This group is characterized by its participation in a joint venture, cooperative research centre or technology centre (97.5\% of the firms in the cluster have this type of relationship), mainly centres with which a university has a formal involvement. A high level of cooperation is also found for the creation of spin-off or start-up firms (31.8\%), in addition to consultancy, R\&D projects and activities related to human resources, which mainly involve receiving trainees. This is the smallest group, comprising 22 cases and accounting for $3 \%$ of the sample. Although it may be related to $\mathrm{H} 1$, this is an unexpected result. It reflects a specific pattern for firms that prefer stable institutionalized relations.

C3 - University facility users: Characterized by their instrumental use of the physical capital of universities. 100\% of the firms in this cluster have used university facilities or equipment, either through leasing, concessions or expert protocols. Consultancy is also an important activity (63.4\%). This group shows moderate values in terms of participating in projects and activities related to human resources. It should be emphasised that there is not one case in this group of a firm that has utilized a patent or participated in the creation of a joint venture. The group comprises 41 cases, representing $5.6 \%$ of the sample. This result contributes towards confirming H3, since the group contains firms that concentrate their strategies on using university infrastructures and services.

C4 - Training and education beneficiaries: The firms in this cluster are characterized by their training of university personnel (100\% of the cases), mostly postgraduates, which is usually their only activity. This is the group that engages less in the other activities, for which very low values are found. It comprises 68 cases and accounts for $9.2 \%$ of the sample. To some extent this group confirms $\mathrm{H} 2$, although it reflects firms with a lower level of involvement, mainly related to the prospect of recruiting qualified workers with university degrees.

C5 - Tacit knowledge users: This group shows high scores for all types of activities related to human resources and is much more active in all of these areas than the previous groups. It also shows high scores for generating or utilizing knowledge (participation ranges from around $72 \%$ of firms in consultancy work and joint R\&D projects to $45 \%$ in contract R\&D projects). The group is also characterized by its lack of use of IPR results. No firm in this group uses patents. Therefore, tacit knowledge seems to be the key feature for engagement in R\&D activities that require close collaboration with university personnel. It includes 66 cases and represents $9 \%$ of the sample. This group is related to H1 since it shows the aggregation of typical exploration activities, as opposed to exploitation activities. Nevertheless, the results in other groups of firms show other combinations of the same elements.

C6 - RED interactors: This group is involved in important consultancy relationships (49\%) and both kinds of R\&D projects (40\% of the firms participate in contract R\&D, 56\% participate in joint R\&D projects) although to a lesser extent than the previous group. One important feature is that it has almost no activities related to training and the exchange of human resources. There are 45 cases in this group, which accounts for $6.1 \%$ of the sample. The mix of channels in this group is consistent with H1. The diverse range of combinations suggests that a sharp differentiation between exploitation and exploration is not recommended. Although this is a useful analytical distinction, it would be necessary to differentiate between the scientific knowledge associated with exploration strategies related to human resources, in comparison to others associated with research projects. 
Table 6

Profile of firm clusters.

$\begin{array}{llllllll}\text { C0 } & \text { C1 } & \text { C2 } & \text { C3 } & \text { C4 } & \text { C5 } & \text { C6 } & \text { Total }\end{array}$

\begin{tabular}{|c|c|c|c|c|c|c|c|c|}
\hline \multicolumn{9}{|l|}{ 1a. Background variables } \\
\hline \multicolumn{9}{|l|}{ Activity sector ${ }^{\mathrm{a}}$} \\
\hline Low and medium-low technology manufacturing & 15.3 & 19.6 & 38.1 & 12.2 & 20.9 & 19.7 & 22.7 & 17.5 \\
\hline Medium-high technology manufacturing & 13.9 & 13.7 & 14.3 & 19.5 & 11.9 & 13.6 & 20.5 & 14.4 \\
\hline High technology manufacturing & 3.8 & 3.9 & 2.0 & 2.4 & 13.4 & 3.0 & 4.5 & 5.7 \\
\hline Technical services & 2.9 & 9.9 & 4.8 & 12.2 & 2.0 & 4.5 & 2.3 & 2.2 \\
\hline Info-tech services & 19.9 & 17.6 & 9.5 & 17.1 & 21.9 & 21.2 & 11.4 & 19.3 \\
\hline Professional, financial and services & 5.3 & 5.8 & 1.0 & 12.2 & 3.0 & 7.6 & 11.4 & 6.4 \\
\hline Transport services & 3.5 & 3.9 & 4.8 & 4.9 & 4.5 & 9.1 & 4.5 & 4.3 \\
\hline Wholesale, retail and personal services & 26.9 & 3.9 & .0 & 9.8 & 13.4 & 6.1 & 13.6 & 19.5 \\
\hline Other & 8.6 & 21.6 & 25.6 & 9.8 & 9.0 & 15.2 & 9.1 & 10.8 \\
\hline Belongs to a corporate group ${ }^{a}$ & 17.9 & 32.1 & 27.3 & 19.5 & 27.9 & 33.3 & 25.0 & 22.1 \\
\hline Age of firm ${ }^{a}$ (less than 7 years) & 17.2 & 24.5 & 18.2 & 19.5 & 19.4 & 15.4 & 20.0 & 18.1 \\
\hline \multicolumn{9}{|l|}{ No. of workers ${ }^{a}$} \\
\hline From 1 to 5 & 39.7 & 19.2 & 9.1 & 26.8 & 17.6 & 13.6 & 20.0 & 30.9 \\
\hline From 6 to 10 & 25.8 & 11.5 & 4.5 & 22.0 & 25.0 & 7.6 & 28.9 & 22.3 \\
\hline From 11 to 25 & 22.5 & 21.2 & 22.7 & 24.4 & 23.5 & 31.8 & 28.9 & 23.9 \\
\hline From 26 to 50 & 7.2 & 25.0 & 9.1 & 2.4 & 13.2 & 16.7 & 11.1 & 9.9 \\
\hline More than 50 & 4.9 & 23.1 & 54.5 & 24.4 & 20.6 & 30.3 & 11.1 & 13.0 \\
\hline$\%$ of the business in the regional market ${ }^{\mathrm{b}}$ & 82.4 & 48.1 & 52.0 & 62.5 & 66.1 & 65.9 & 55.8 & 73.2 \\
\hline$\%$ of the business in the national market ${ }^{\mathrm{b}}$ & 94.3 & 75.2 & 79.0 & 81.9 & 92.7 & 84.5 & 83.6 & 90.1 \\
\hline$\%$ of the business in the international market ${ }^{\mathrm{b}}$ & 3.8 & 15.3 & 16.4 & 18.1 & 4.3 & 10.9 & 9.8 & 6.9 \\
\hline Turnover $^{\mathrm{b}}$ (in millions of euros) & 2.7 & 3.4 & 4.2 & 3.0 & 3.3 & 3.9 & 3.2 & 3.0 \\
\hline \multicolumn{9}{|l|}{ 1b. Absorptive capacity variables } \\
\hline$\%$ of workers with $\mathrm{PhD}^{\mathrm{b}}$ & 0.3 & 4.3 & 2.1 & 3.2 & 1.1 & 0.6 & 1.9 & 1.0 \\
\hline$\%$ of workers with any HE degree ${ }^{b}$ & 12.7 & 39.6 & 29.7 & 53.3 & 28.0 & 36.5 & 31.8 & 22.1 \\
\hline \multicolumn{9}{|l|}{$\mathrm{R} \& \mathrm{D}$ department $\mathrm{a}^{\mathrm{a}}$} \\
\hline Yes, in this location & 8.1 & 54.7 & 54.5 & 48.8 & 26.5 & 40.0 & 24.4 & 20.8 \\
\hline Yes, in another location & 3.2 & 1.9 & 4.5 & 2.4 & 4.4 & 6.2 & 4.4 & 3.6 \\
\hline No & 88.7 & 43.4 & 40.9 & 48.8 & 69.1 & 53.8 & 71.1 & 75.6 \\
\hline Numbers of workers in the R\&D department ${ }^{\mathrm{b}}$ & 0.5 & 5.1 & 6.5 & 5.4 & 2.0 & 3.4 & 1.6 & 1.8 \\
\hline Product innovation in the last 5 years ${ }^{\mathrm{a}}$ & 44.2 & 81.1 & 86.4 & 68.3 & 67.6 & 77.3 & 68.9 & 56.3 \\
\hline Process innovation in the last 5 years ${ }^{\mathrm{a}}$ & 35.2 & 56.6 & 95.5 & 65.9 & 50.7 & 59.1 & 60.0 & 45.5 \\
\hline \multicolumn{9}{|l|}{ 2. Strategy variables } \\
\hline Importance of external organisations as sources for innovation ${ }^{\mathrm{b}}$ & 3.1 & 4.8 & 3.9 & 4.0 & 4.3 & 4.3 & 4.8 & 3.6 \\
\hline Importance of knowledge intensive business services as sources for innovation ${ }^{\mathrm{b}}$ & 4.9 & 7.1 & 8.0 & 7.0 & 6.1 & 7.6 & 6.0 & 5.7 \\
\hline \multicolumn{9}{|l|}{ 3. Situational variables } \\
\hline \multicolumn{9}{|l|}{ Location of the firm ${ }^{\mathrm{b}}$} \\
\hline Science or technology park & 1.6 & 17.3 & 36.4 & 24.4 & 16.2 & 16.7 & 6.7 & 8.1 \\
\hline Industrial district - area & 30.2 & 30.8 & 18.2 & 22.0 & 32.4 & 25.8 & 22.2 & 28.7 \\
\hline Urban area - city centre & 46.3 & 17.3 & 18.2 & 41.5 & 26.5 & 33.3 & 33.3 & 39.2 \\
\hline Urban area - suburbs & 14.2 & 19.2 & 13.6 & 2.4 & 20.6 & 16.7 & 20.0 & 15.1 \\
\hline Rural area & 7.2 & 13.5 & 9.1 & 7.3 & 4.4 & 7.6 & 17.8 & 8.1 \\
\hline Other & 0.5 & 1.9 & 4.5 & 2.4 & & & & 0.7 \\
\hline \multicolumn{9}{|l|}{ Membership of other organisations ${ }^{a}$} \\
\hline Associated with a technology centre & 2.6 & 7.3 & 32.9 & 6.9 & 1.9 & 8.8 & 11.6 & 10.8 \\
\hline Associated with a regional innovation network (CIT-Regional centres for innovation) & 0.7 & 9.8 & 4.8 & 3.4 & 3.6 & 3.8 & 3.1 & 4.1 \\
\hline Associated with a research centre & 0.4 & 2.4 & 10.1 & 3.4 & 1.9 & 2.6 & 3.1 & 3.0 \\
\hline Member of business association related to innovation activities & 14.9 & 24.4 & 14.3 & 41.7 & 35.2 & 24.5 & 21.9 & 29.4 \\
\hline Member of employer association & 15.2 & 19.5 & 9.5 & 6.9 & 16.7 & 15.1 & 12.5 & 14.8 \\
\hline Member of other business association (sector or trade associations, local associations, local chambers of commerce, etc.) & 59.5 & 34.1 & 28.6 & 37.6 & 42.6 & 47.2 & 43.8 & 50.1 \\
\hline University located in the same province as the firm & - & 20.0 & 83.0 & 83.3 & 92.7 & 91.2 & 86.4 & 72.2 \\
\hline
\end{tabular}

\footnotetext{
a Percent in columns.
}

b Mean.

\subsection{Determinants of university-industry interactions}

The analysis so far does not show a clear profile for the clusters in terms of structure, strategy or situation variables, although the differences suggest that these variables shape these kinds of relationships. An alternative way of looking at the results involves exploring the possible influences of different variables on the specific modes of interaction reflected by a combination of channels. Variables commonly used in empirical research may have different effects on the propensity to establish university-industry links, depending on the kinds of relationships in which firms are engaged.

The dependent variable used in the econometric analysis is a transformation of the original university-industry interactions variables. The dependent variables are binary, assuming the value 1 if the firm has had any interaction in the specific type of factor. The independent variables consider cluster membership, background, absorptive capacity, strategy and situational variables. The analysis used a PROBIT estimation to detect relationships between these variables. ${ }^{13}$ The results of the estimation process are presented in Table 7.

Starting with cluster membership, a clear pattern can be noticed. The six types of clusters are involved in particular types of interactions. It can be confirmed that all types of firms participate in F1 Generation and adaptation of knowledge activities and informal interactions, clearly connected with exploration. F3 - Training and exchange of HR, another exploration-based link, is also influenced by membership in all types of clusters except R\&D Interactors. The

\footnotetext{
${ }^{13}$ A confirmatory model was also estimated using OLS and a different dependent variable (the intensity in each latent dimension achieved through factor analysis, constructed with the sum of the number of interactions in each specific channel). The effects of the cluster membership were also controlled by excluding the dummies from the PROBIT model. The results seem to be consistent in all situations.
} 
Table 7

Determinants of university-industry interactions (PROBIT estimation process).

\begin{tabular}{|c|c|c|c|c|c|c|}
\hline \multirow[t]{2}{*}{ Variable } & \multirow{2}{*}{$\begin{array}{l}\text { F1 - Exploration } \\
\text { Generation \& } \\
\text { adaptation of } \\
\text { knowledge activities }\end{array}$} & \multirow{2}{*}{$\begin{array}{l}\mathrm{F} 2-\text { Exploitation } \\
\text { Creation of new } \\
\text { organisations }\end{array}$} & \multirow{2}{*}{$\begin{array}{l}\text { F3 - Exploration } \\
\text { Training \& } \\
\text { exchange of HR }\end{array}$} & \multirow{2}{*}{$\frac{\text { F4 - Exploitation }}{\text { IPR }}$} & \multirow{2}{*}{$\begin{array}{l}\text { F5 - Exploitation } \\
\text { Facilities \& } \\
\text { equipment }\end{array}$} & \multirow{2}{*}{$\begin{array}{l}\text { Exploration } \\
\text { Informal } \\
\text { links }\end{array}$} \\
\hline & & & & & & \\
\hline C - Constant & $-2.477^{* * *}$ & $-6.700^{* * *}$ & $-2.945^{* * *}$ & -12.139 & $-3.527^{* * *}$ & $-1.975^{* * *}$ \\
\hline \multicolumn{7}{|l|}{ Cluster membership } \\
\hline C1 - Dummy 1 if IPR Exploiters & $2.849^{* * *}$ & $3.104^{* * *}$ & $2.607^{* * *}$ & 10.002 & $1.077^{* *}$ & $1.622^{* * *}$ \\
\hline C2 - Institutionalized Interactors & $1.946^{* * *}$ & $5.933^{* * *}$ & $2.070^{* * *}$ & 7.949 & $1.472^{* * *}$ & $1.506^{* * *}$ \\
\hline C3 - University facility users & $2.099^{* * *}$ & 1.103 & $1.952^{* * *}$ & -0.879 & $3.475^{* * *}$ & $1.169^{* * *}$ \\
\hline C4 - Training beneficiaries \& Education & $1.091^{* * *}$ & -0.449 & $2.952^{* * *}$ & -1.244 & -6.628 & $0.826^{* * *}$ \\
\hline C5 - Tacit knowledge users & $2.825^{* * *}$ & -7.806 & $3.422^{* * *}$ & -0.966 & -8.703 & $2.058^{* * *}$ \\
\hline C6 - R\&D Interactors & $3.295^{* * *}$ & -7.013 & -0.164 & 6.849 & 0.444 & $1.337^{* * *}$ \\
\hline \multicolumn{7}{|l|}{ Background } \\
\hline SERV - Dummy 1 if firm is from the service sector - PITEC & -0.258 & 0.709 & -0.400 & 0.159 & -0.292 & -0.070 \\
\hline $\begin{array}{l}\text { TECN_PITEC - Dummy } 1 \text { if firm is from medium and high } \\
\text { technology sectors }\end{array}$ & -0.140 & -0.296 & -0.416 & 0.443 & 0.075 & -0.081 \\
\hline GROUP - Dummy 1 if firm belongs to a corporate group & -0.095 & -0.775 & -0.056 & 0.083 & $-0.943^{*}$ & 0.044 \\
\hline EMP - Number of employees & 0.001 & 0.002 & -0.000 & -0.002 & $0.004^{* *}$ & $-0.001^{*}$ \\
\hline EXPOR - Dummy 1 if firm is exporter & $0.452^{* *}$ & 0.097 & $0.607^{* * *}$ & -0.081 & $0.662^{* *}$ & $0.325^{* *}$ \\
\hline TURNOVER1M - Dummy 1 if turnover is higher than $1 \mathrm{M} €$ & $0.382^{* *}$ & 0.150 & 0.069 & -0.798 & -0.005 & -0.061 \\
\hline STARTUP - Dummy 1 if firm is less than 7 years old & 0.183 & $1.208^{*}$ & 0.069 & -0.710 & 0.146 & 0.081 \\
\hline \multicolumn{7}{|l|}{ Absorptive capacity } \\
\hline PHD - Dummy 1 if firm has staff with PhD degrees & $0.486^{*}$ & $0.960^{* *}$ & 0.162 & 0.396 & 0.450 & -0.225 \\
\hline HUMANCAP - Percentage of staff with a higher education degree & 0.003 & -0.001 & $0.006^{*}$ & -0.013 & 0.006 & $0.005^{* *}$ \\
\hline INNO_PROC - Dummy 1 if firm has introduced new processes & -0.029 & 0.057 & 0.197 & $0.877^{* * *}$ & -0.311 & 0.074 \\
\hline INNO_PROD - Dummy 1 if firm has introduced new products & 0.112 & 0.301 & -0.065 & -0.545 & -0.471 & 0.110 \\
\hline INNOV_ACT - Range of investments in innovation activities & -0.010 & -0.235 & 0.070 & 0.174 & 0.133 & -0.043 \\
\hline RD_DEP1 - Dummy 1 if firm has R\&D department & 0.155 & -0.399 & -0.082 & -0.133 & 0.037 & -0.048 \\
\hline \multicolumn{7}{|l|}{ Strategy } \\
\hline EXT_SOURCE - Dummy 1 if external knowledge sources used & -0.262 & 0.908 & -0.004 & 0.692 & -0.402 & 0.153 \\
\hline KIBS - Range of use of KIBS mechanisms & -0.007 & 0.134 & -0.001 & -0.125 & 0.000 & -0.009 \\
\hline PAT - Dummy 1 if firm has registered patents & 0.156 & 0.462 & 0.116 & $1.183^{* *}$ & 0.499 & 0.124 \\
\hline PUBSUP - Dummy 1 if firm uses public innovation financial tools & $1.017^{* * *}$ & $1.539^{* *}$ & $0.641^{* * *}$ & 0.413 & 0.337 & 0.175 \\
\hline \multicolumn{7}{|l|}{ Situation } \\
\hline $\begin{array}{l}\text { INT_IND - Dummy } 1 \text { if firm is located in high intensity } \\
\text { industrial area }\end{array}$ & -0.102 & 0.208 & $0.379^{* *}$ & $-1.403^{* *}$ & 0.282 & 0.124 \\
\hline STPARK - Dummy 1 if firm is located in S\&T Park & $0.493^{*}$ & 0.305 & 0.405 & -0.137 & -0.293 & $0.345^{*}$ \\
\hline UNIV - Dummy 1 if firm is close to university & -0.127 & 1.300 & 0.054 & $2.195^{* * *}$ & 0.400 & 0.116 \\
\hline Probability (LR stat) & 0.000 & 0.000 & 0.000 & 0.000 & 0.000 & 0.000 \\
\hline McFadden R-squared & 0.636 & 0.757 & 0.673 & 0.735 & 0.683 & 0.316 \\
\hline Obs with Dep $=0$ & 547 & 695 & 538 & 709 & 689 & 590 \\
\hline Obs with Dep $=1$ & 190 & 42 & 199 & 28 & 48 & 147 \\
\hline
\end{tabular}

$\mathrm{N}=737$. Software used: E-Views.

*** Significant at 0.01 .

** Significant at 0.05 .

* Significant at 0.1 .

exploitation-based links are only used by particular types of firms, which supplement these with exploration. This is the case with F2 - Creation of new organisations, in which C1 - IPR exploiters and C2 - Institutionalized interactors are the most significant clusters, and with F5 - Facilities and equipment, in which these two clusters are joined by C3 - University facility users. Cluster membership is not statistically significant in F4 - IPR, even though the higher coefficient associated with C1 - IPR Exploiters should be noted. The analysis of cluster membership leads to the conclusion that specific types of firms only use exploration mechanisms, whereas others supplement exploration with exploitation of knowledge, thus providing clear evidence that $\mathrm{H} 1$ should not be rejected.

Secondly, it is interesting to analyse the results according to the structural variables. Belonging to a corporate group negatively affects the likelihood of engaging in exploitation of university facilities and equipment (F5). Conversely, the size of the firm, measured by the number of employees, has a positive effect on the use of this channel. The number of employees negatively influences the development of informal relationships, with larger firms establishing more formal interactions. Export activity is a relevant predictor of the existence of university-industry links, namely regarding activities related to the generation and adaptation of knowledge (F1), human resources (F2), facilities and equipment (F5) and informal activities. The size of firm, as measured by the turnover, is also important in terms of engagement in knowledge generation and adaptation activities (F1).

Thirdly, absorptive capacity is shown to be relevant to university-industry interactions, although the analysis does not provide a clear pattern to confirm H2. High-level qualifications in firms, measured by the presence of staff with PhD degrees, is a powerful catalyst for exploration through knowledge generation activities (F1) and exploitation through the creation of new organisations (F2). This is in line with $\mathrm{H} 2$, which proposes that firms with a higher absorptive capacity combine exploration and exploitation activities. The introduction of process innovation is also a positive inducer for exploitation of IPR (F4). However, human capital in the form of qualifications, measured by the percentage of staff with higher education degrees, is positive and significant for exploration activities only, namely the training and exchange of human resources (F3) and informal relationships. This result does not confirm $\mathrm{H} 2$, as the higher 
absorptive capacity of firms with more qualified personnel is not reflected in a mix of exploration and exploitation activities.

Fourthly, the strategic variables reflect the importance of public programmes which foster university-industry interactions. Firms that have benefitted from public support for innovation were more likely to engage in activities involving knowledge generation and use (F1), involvement in new organisations (F2) and training and exchange of human resources (F3), all of which receive a high level of attention in public initiatives. The active use and ownership of patents leads to further exploitation of IPR generated by universities (F4). On the other hand, the range of external knowledge sources used or the use of KIBS does not reveal a significant effect on any type of interaction.

Finally, the situational variables clearly reflect the influence of location on university-industry interactions. The location of a firm in a high intensity industrial area fosters exploration through engagement in human resources training and exchanges (F3), but has a negative impact on the exploitation of IPR (F5). Location in S\&T parks is a catalyst for exploration, facilitating informal contacts and the generation and adaptation of knowledge (F1). Physical proximity to a university only has a clear impact on the exploitation of IPR (F5). Since IPR exploiters use a range of channels, this result provides good evidence that proximity is relevant to achieving a stronger level of university-industry interaction. Although not fully confirming $\mathrm{H} 3$, the results are not strong enough to reject the hypothesis that physical proximity to a university is a catalyst for university-industry interactions. In a peripheral region with lower technological capacities, location appears to facilitate interaction but the barriers to benefitting from the proximity of a university remain high.

\section{Conclusion}

This study shows that when the ways in which firms in a peripheral innovation system interact with universities are observed in detail a wide range of interactions emerge. The most frequent relationships are those related to the training and exchange of human resources, as well as consultancy work. The development of $R \& D$ projects and the use of university facilities are less common. The least frequent activities include the exploitation of patents, the creation of spin-offs and participation in joint ventures. These results support the thesis that universities are an important source of tacit knowledge, through the training of human resources needed for both recruitment of skilled workers and to enhance the use of results from collaborative projects and consultancy work. The study also demonstrates the need to adapt the indicators for knowledge transfer to regional environments.

The main contribution of this article is the development a typology of firms that provides a number of theoretical and policy implications for university-industry interactions. Firstly, firms that interact with universities tend to use more than one channel at the same time, especially firms with a higher absorptive capacity. Firms that focus on exploiting IPR develop this in parallel to other exploration and training activities and also use university services extensively. Patent exploitation goes hand in hand with other activities that help explore knowledge. Secondly, the typology shows that there are typical modes of knowledge transfer when interacting with universities. Some firms concentrate on special organisations specifically designed for collaboration, whilst others concentrate on using university facilities and consultancy work, or on certain forms of training. Thirdly, some characteristics of the firms are associated with specific combinations of channels. Although it is not possible to find clear patterns, it is evident that absorptive capacity influences particular science-related modes of knowledge transfer. SMEs with less absorptive capacity interact less with universities. Nevertheless, some of them make use of specific modes of knowledge transfer adapted to their needs. In particular, the training of human resources remains a central activity across the different groups of firms, leading both to the conclusion that absorptive capacity is an important factor and the suggestion that absorptive capacity also needs to be characterized by activities developed in addition to the available resources. Finally, in peripheral innovation systems location appears to facilitate interaction, although this study shows that the benefits of proximity to a university are not necessarily evident.

These findings have relevant policy implications for peripheral innovation systems. Access to universities is extremely varied and responds to very different rationales, depending on a firm's possibilities and strategies. It should be noted that R\&D-related activities, especially if IPR-based, do not play a major role in most firms, even the more innovative ones. R\&D-intensive activities, particularly IPR exploitation, are possibly just the tip of the iceberg that emerges only when firms have sufficient capacity and have engaged in a wide range of previous interactions with universities. Given this, the situational context should be considered from a broader perspective which includes the different actors and institutions in the regional innovation system, rather than focusing only on the role of universities. Governments should not concentrate public incentives on specific interactions aimed at exploiting the codified knowledge available in universities, but should aim to use incentives to adapt interactions to the specific composition of the industrial fabric.

\section{Acknowledgements}

Hugo Pinto is supported by FCT - Portuguese Foundation for Science and Technology (SFRH/BPD/84038/2012). This article has used data from the project "Conditioning factors for the generation and use of scientific research in Andalusia" funded by the Regional R\&D Scheme of the Government of Andalusia (PAIDI) (Grant reference SEJ-2005-801).

\section{Annex}

\section{List I: Types of interactions}

1. Consultancy work provided by a university or public research centre (reports, technical upgrading or advice, mediated by a formal agreement).

2. Contract R\&D projects (commissioning of projects financed solely by the firm).

3. Joint R\&D projects (projects jointly financed or funded with public aid from R\&D calls, such as the national R\&D plan and the EU Framework Programme).

4. Use of university facilities or equipment (testing, calibrations, use of scientific instruments, analysis, etc.).

5. Exploitation of a patent or other IPR (joint patenting, patent licensing, agreements on software or biological varieties).

6. Training of university personnel by the enterprise (official internships, temporary stays for university students at the firm, including doctoral candidates).

7. Temporary exchange of personnel (stays for firm's researchers and technicians at the university).

8. Specific training of firm's personnel by the university (specific courses, seminars and workshops designed for firms).

9. Participation in a stable joint venture, with the university as one of the partners (collaborative research centres, joint technology centres, public-private partnerships with commercial purposes).

10. Creation of a new firm (spin-offs or start-ups in collaboration with a university).

11. Informal relations with university personnel (personal aid, advice, and information not based on a formal agreement with a university body).

12. Other types of collaboration activities (open question later coded as: dissemination, conferences, encounters, seminars, joint trips and other unspecified links). 
Table I

Company strategy on open innovation: information for the compound variables. Percentage of firms declaring that the proposed activity or organisation is important or very important as a source of innovation.

\begin{tabular}{|c|c|c|c|}
\hline $\begin{array}{l}\text { Knowledge intensive } \\
\text { business services }\end{array}$ & $\%$ & External organisations & $\%$ \\
\hline $\begin{array}{l}\text { 1. Business development } \\
\text { advice }\end{array}$ & 44.6 & 1. Specialized suppliers & 81.7 \\
\hline 2. Planning advice & 40.5 & 2. Other firms in the same sector & 68.3 \\
\hline $\begin{array}{l}\text { 3. Marketing and } \\
\text { promotional advice }\end{array}$ & 49.3 & 3. Technological consultants & 42.4 \\
\hline $\begin{array}{l}\text { 4. Marketing and product } \\
\text { research }\end{array}$ & 60.9 & 4. Commercial laboratories & 38.6 \\
\hline $\begin{array}{l}\text { 5. Accounting and financial } \\
\text { advice }\end{array}$ & 70.9 & $\begin{array}{l}\text { 5. Universities and public research } \\
\text { centres }\end{array}$ & 49.6 \\
\hline $\begin{array}{l}\text { 6. Information Technology } \\
\text { Services }\end{array}$ & 58.4 & $\begin{array}{l}\text { 6. Regional technology and } \\
\text { innovation centres }\end{array}$ & 49.8 \\
\hline 7. Human resources training & 73.6 & 7. Conferences and specialist events & 69.8 \\
\hline 8. Recruitment & 54.8 & 8. Local government & 32.4 \\
\hline 9. Accreditation & 48.5 & 9. Regional government & 39.9 \\
\hline 10. Legal services & 45.8 & 10. Company associations & 53.6 \\
\hline 11. E-commerce & 35.0 & 11. Informal networks & 37.3 \\
\hline Compound variable (mean) & 5.7 & Compound variable (mean) & 3.6 \\
\hline Cronbach alpha & 0.69 & Cronbach alpha & 0.61 \\
\hline
\end{tabular}

\section{References}

Agrawal, A., Henderson, R., 2002. Putting patents in context: exploring knowledge transfer from MIT. Management Science vol. 48(1). INFORMS, pp. 44-60.

Alegre, J., Chiva, R., 2008. Assessing the impact of organizational learning capability on product innovation performance: an empirical test. Technovation 28, 315-326.

Arundel, A., Geuna, A., 2004. Proximity and the use of public science by innovative European firms. Econ. Innov. New Technol. 13, 559-580.

Asheim, B., Gertler, M., 2005. The geography of innovation: regional innovation systems. In: Fagerberg, J., Mowery, D., Nelson, R. (Eds.), The Oxford Handbook of Innovation. Oxford University press, New York, pp. 291-317.

Asheim, B.T., Isaksen, A., 2002. Regional innovation systems: the integration of local 'sticky' and global 'ubiquitous' knowledge. J. Technol. Transfer. 27, 77-86.

Autio, E., Hameri, A., Nordberg, M., 1996. A framework of motivations for industry-big science collaboration: a case study. J. Eng. Technol. Manag. 13, 301-314.

Azagra-Caro, J.M., Carat, G., Pontikakis, D., 2010. Inclining the columns to make the temple look straight: a first glance at monetary indicators on university-industry cooperation. Res. Eval. 19 (2), 119-128.

Beise, M., Stahl, H., 1999. Public research and industrial innovations in Germany. Res. Policy 28 (4), 397-422.

Bekkers, R., Freitas, I.M.B., 2008. Analysing knowledge transfer channels between universities and industry: to what degree do sectors also matter? Res. Policy 37 (10), 1837-1853.

Belderbos, R., Carree, M., Lokshin, B., 2004. Cooperative R\&D and firm performance. Res. Policy 33 (10), 1477-1492.

Bonnaccorsi, C., Daraio, C. (Eds.), 2007. Universities and Strategic Knowledge Creation. Edward Elgar, Cheltenham.

Boschma, R., 2005. Proximity and innovation: a critical assessment. Reg. Stud. 39 (1), 61-74.

Boucher, G., Conway, Ch., Van Der Meer, E., 2003. Tiers of engagement by universities in their region's development. Reg. Stud. 37 (9), 887-897.

Bruneel, J., D'Este, P., Salter, A., 2010. Investigating the factors that diminish the barriers to university-industry collaboration. Res. Policy 39 (7), 858-868.

Canton, E., Lanser, D., Noailly, J., Rensman, M., Van De Ven, J., 2005. Crossing Borders: When Science Meets Industry. CPB Netherlands Bureau for Economic Policy Analysis, The Hague.

Carayol, N., 2003. Objectives, agreements and matching in science-industry collaborations: reassembling the pieces of the puzzle. Res. Policy 32 (6), 887-908.

Chesborough, H., 2003. Open Innovation. Harvard University Press, Cambridge, MA.

Chiesa, V., Manzini, R., 1998. Organizing for technological collaborations: a managerial perspective. R\&D Manag. 28 (3), 199-212.

CICE, 2006. Plan Andaluz de Investigación, Desarrollo e Innovación Tecnológica. Servicio de Publicaciones de la CICE, Sevilla.

Cohen, W., Levinthal, D., 1989. Innovation and learning: the two faces of R\&D. Econ. J. 99, 569-596.

Cohen, W., Levinthal, D., 1990. Absorptive capacity: a new perspective on learning and innovation. Adm. Sci. Q. 35, 129-152.

Cohen, W.M., Nelson, R.R., Walsh, J., 2002. Links and impacts: the influence of public research on industrial R\&D. Manag. Sci. 48, 1-23.

Cooke, P., Piccaluga, A. (Eds.), 2004. Regional Economies as Knowledge Laboratories. Edward Elgar, Cheltenham.

Cyert, R.M., Goodman, P.S., 1997. Creating effective university-industry alliances: an organizational perspective. Organ. Dyn. 4-57 (Spring).
D'Este, P., Patel, P., 2007. University-industry linkages in the UK: what are the factors underlying the variety of interactions with industry? Res. Policy 36, 1295-1482

Davenport, S., 2005. Exploring the role of proximity in SME knowledge acquisition. Res. Policy 34 (5), 683-701.

D'Este, P., Iammarino, S., 2010. The spatial profile of university-business research partnerships. Pap. Reg. Sci. 89 (2), 335-350.

Dosi, G., Llerena, P., Labini, M.S., 2006. The relationships between science, technologies and their industrial exploitation: an illustration through the myths and realities of the so-called 'European Paradox'. Res. Policy 35 (10), 1450-1464.

Duysters, G., Lokshin, B., 2007. Determinants of alliance portfolio complexity and its effect on innovative performance of companies. UNU-MERIT. Working Paper Series (2007-033).

Falk, R., 2007. Measuring the effects of public support schemes on firms' innovation activities: survey evidence from Austria. Res. Policy 36 (5), 665-679.

Fernández-Esquinas, M., Espinosa-De-Los-Monteros, E., Jiménez-Buedo, M., Pérez-Yruela M., 2008. Prospectiva de Recursos Humanos en el Sistema Andaluz de Universidades. IESA-CSIC/Consejería de Educación, Ciencia y Empresa, Córdoba.

Fontana, R., Geuna, A., Matt, M., 2006. Factors affecting university-industry R\&D projects: the importance of searching, screening and signaling. Res. Policy 35, 309-323.

Fritsch, M., Schwirten, C., 1999. Enterprise-university cooperation and the role of public research institutions in regional innovation systems. Ind. Innov. 6 (1), 69-84.

García Aracil, A., Fernández De Lucio, I., 2008. Industry-university interactions in a peripheral European region: an empirical study of Valencian firms. Reg. Stud. 42 (2), 215-227.

Grillitsch, M., Trippl, M., 2014. Combining knowledge from different sources, channels and geographical scales. Eur. Plan. Stud. 22 (1), 2305-2325.

Gulbrandsen, M., Slipersaeter, S., 2007. The third mission and the entrepreneurial university model. In: Bonaccorsi, C., Daraio, C. (Eds.), Universities and Strategic Knowledge Creation. Edward Elgar, Cheltenham, pp. 112-143.

Gulbrandsen, M., Mowery, D., Feldman, M., 2011. Introduction to the special issue: heterogeneity and university-industry interactions. Res. Policy 40 (1), 1-5.

Hall, B., Link, A., Scott, J., 2000. Universities as research partners. Working Paper No. 7643. National Bureau of Economic Research.

Hicks, D., Breitzman, T., Olivastro, D., Hamilton, K., 2001. The changing composition of innovative activity in the US: a portrait based on patent analysis. Res. Policy 30, 681-703.

Hirsch-Kreinsen, H., 2008. "Low-technology": a forgotten sector in innovation policy J. Technol. Manag. Innov. 3 (3), 11-20.

INE, 2010. Estadística de I+D en España. INE, Madrid.

Jaffe, A.B., 1989. Real effects of academic research. Am. Econ. Rev. 79 (5), 957-970.

Jensen, M.B., Johnson, B., Lorenz, E., Lundvall, B.-A., 2007. Forms of knowledge and modes of innovation. Res. Policy 36, 680-693.

Junta De Andalucía, 2003. Andalucía: segunda modernización. Estrategias y propuestas Consejería de la Presidencia, Sevilla.

Larsen, M.T., 2011. The implications of academic enterprise for public science: overview of the empirical evidence. Res. Policy 40 (1), 6-19.

Laursen, K., Salter, A., 2004. Searching high and low: what types of firms use universities as a source of innovation? Res. Policy 33, 1201-1215.

Laursen, K., Salter, A., 2014. The paradox of openness: appropriability, external search and collaboration. Res. Policy 43, 867-878.

Lepori, B., Barré, R., Filliatreau, G., 2008. New perspectives and challenges for the design of S\&T indicators. Res. Eval. 17 (1), 33-44.

Levy, R., Roux, P., Wolff, S., 2009. An analysis of science-industry collaborative patterns in a large European university. J. Technol. Transfer. 34, 1-23.

Löfsten, H., Lindelöf, P., 2002. Science parks and the growth of new technology-based firms: academic-industry links, innovation and markets. Res. Policy 31 (6), 859-876.

Lööf, H., Heshmati, A., 2002. Knowledge capital and performance heterogeneity: a firm level innovation study. Int. J. Prod. Econ. 76 (1), 61-85.

Lorenz, E., Lundvall, B.-A. (Eds.), 2006. How Europe's Economies Learn: Coordinating Competing Models. Oxford University Press, Oxford.

Mangematin, V., Nesta, L., 1999. What kind of knowledge can a firm absorb? Int J. Technol. Manag. 18 (3/4), 149-172.

Mansfield, E., 1995. Academic research underlying industrial innovations: sources, characteristics, and financing. Rev. Econ. Stat. 77 (1), 55-65.

Mansfield, E., 1998. Academic research and industrial innovation: an update of empirical findings. Res. Policy 26, 773-776.

March, J.G., 1991. Exploration and exploitation in organizational earning. Organ. Sci. 2 71-87.

Miles, I., Kastrinos, N., Flanagan, K., Bilderbeek, R., Den Hertog, P., 1995. Knowledgeintensive Business Services: Users, Carriers and Sources of Innovation, European Innovation Monitoring Systems, EIMS Publication No 15. Innovation Programme, DGXIII, Luxembourg.

Mohnen, P., Hoareau, C., 2003. What type of enterprise forges close links with universities and government labs? Evidence from CIS 2. Manag. Decis. Econ. 24, 133-146.

Molas-Gallart, J., Salter, A., Patel, P., Scott, A., Duran, J., 2002. Measuring third stream activities. Final Report to the Russell Group of Universities. SPRU, University of Sussex, Brighton.

Mora-Valentín, E.M., Montoro-Sanchez, A., Guerras-Martin, L.A., 2004. Determining factors in the success of R\&D cooperative agreements between firms and research organizations. Res. Policy 33, 17-40.

Mowery, D.C., Sampat, B.N., 2005. Universities in national innovation systems. In: Fagerberg, J., Mowery, D.C., Nelson, R. (Eds.), The Oxford Handbook of Innovation. Oxford University Press, Oxford, pp. 209-239.

Nonaka, I., Tagueuchi, H., 1995. The knowledge-creating Company: How the Japanese Companies Create the Dynamics of Innovation. Basil Blackwell, Oxford. 
Nooteboom, B., Haverbekeb, W.V., Duystersc, G., Gilsing, V., Van Den Oordc, A., 2007. Optimal cognitive distance and absorptive capacity. Res. Policy 36 (7), 1016-1034.

OECD, 2002. Benchmarking Industry-Science Relationships. OECD, Paris.

OECD, 2007. Higher Education and Regions: Globally Competitive, Locally Engaged. OECD, Paris.

Owen-Smith, J., Powell, W., 2004. Knowledge networks as channels and conduits: the effects of spillovers in the Boston biotechnology community. Organ. Sci. 15, $5-21$.

Pavitt, K.L.R., 2001. Public policies to support basic research: what can the rest of the world learn from US theory and practice? (and what they should not learn). Ind. Corp. Chang. 10, 761-779.

Perkmann, M., Walsh, K., 2007. University-industry relationships and open innovation: towards a research agenda. Int. J. Manag. Rev. 9 (4), 259-280.

Perkmann, M., Tartari, V., Mckelvey, M., Autio, E., Broström, A., D'Este, P., Fini, R., Geuna, A. Grimaldi, R., Hughes, A., Kitson, M., Krabel, S., Llerena, P., Lissoni, F., Salter, A., Sobrero, M., 2013. Academic engagement and commercialisation: a review of the literature on university-industry relations. Res. Policy 42 (2), 423-442.

Pinto, H., Fernández-Esquinas, M., Uyarra, E., 2013. Universities and Knowledge-Intensive Business Services (KIBS) as Sources of Knowledge for Innovative Firms in Peripheral Regions, Regional Studies. http://dx.doi.org/10.1080/00343404.2013.857396 (Published online: 18 Dec 2013).

PITEC, 2005. La innovación en la empresa española. FECYT-SISE, Madrid.

Powell, W., Koput, K., Smith-Doerr, L., 1996. Interorganizational collaboration and the locus of innovation: networks of learning in biotechnology. Adm. Sci. Q. 41, 116-145.

Ramos Vielba, I., Fernández-Esquinas, M., 2011. Beneath the tip of the iceberg: exploring the multiple forms of university-industry linkages. High. Educ. 64 (2), 237-265.

Salter, A., Martin, B.R., 2001. The economic benefits of publicly funded basic research: a critical review. Res. Policy 30, 509-532.

Schartinger, D., Rammer, C., Fischer, M.M., Frölich, J., 2002. Knowledge interactions between universities and industry in Austria: sectoral patterns and determinants. Res. Policy 31, 303-328.

Shane, S., 2002. Selling university technology: patterns from MIT. Manag. Sci. 48, 122-138.

Strambach, S., Klement, B., 2012. Cumulative and combinatorial micro-dynamics of knowledge: the role of space and place in knowledge integration. Eur. Plan. Stud. 20, 1843-1866.

Tether, B.S., Tajar, A., 2008. Beyond industry-university links: sourcing knowledge for innovation from consultants, private research organisations and the public sciencebase. Res. Policy 37 (6-7), 1079-1095.

Turpin, T., Fernández-Esquinas, M., 2011. The policy rationale for cross sector research collaboration and contemporary consequences. Sci. Public Policy 38 (2), 82-87.

Uyarra, E., 2010. Conceptualizing the regional roles of universities, implications and contradictions. Eur. Plan. Stud. 18 (8), 1227-1246.

Zahra, S.A., George, G., 2002. Absorptive capacity: a review, reconceptualization, and extension. Acad. Manag. Rev. 27 (2), 185-203.

Zucker, L., Darby, M., Brewer, M., 1998. Intellectual capital and the birth of the US biotechnology enterprises. Am. Econ. Rev. 88, 290-306.
Manuel Fernández-Esquinas is a research scientist at the Institute for Advanced Social Studies (IESA), an official centre of the Spanish National Research Council (CSIC). He has worked as an applied sociologist conducting extensive studies on public opinion polls, public policy analysis, social problems and programme evaluation. He has also worked as evaluator and consultant for the Spanish Ministry for Science and Innovation and several regional governments. He is currently the Vice-president for Research of the Spanish Sociological Association, and Spanish delegate at the OECD Committee for Science and Technology Policy. His main research interests are on university-industry relationships, entrepreneurship and the effects of knowledge transfer on firm innovation.

Hugo Pinto has PhD in Economics-Knowledge and Innovation (University of Coimbra), MSc in Regional Economics and BA in Economics (University of Algarve). Hugo Pinto was project manager in several R\&D institutions in Portugal (BIC Algarve-Huelva, University of Algarve, Centre of Marine Sciences, and University of Aveiro). Currently he is a post-doctoral research fellow at Centre for Social Studies, University of Coimbra. At the University of Algarve, he is a Visiting Professor in the Faculty of Economics and an associate member of CIEO - Research Centre on Spatial and Organizational Dynamics. His research interests are innovation systems, knowledge production and transfer, varieties of capitalism, emergence of maritime clusters, and the role of universities in regional development.

Manuel Pérez Yruela is a Full Professor of Sociology at the Spanish Scientific Research Council. He studied sociology at the Complutense University of Madrid (Spain, 1971-74), Lancaster University (1976-77) and Brunel West London University (1978-79). He is also an agricultural engineer (Polytechnic University of Madrid, 1965-1970). From 1992 to 2009, he was the Director of the Institute for Advanced Social Studies (IESA) located in Córdoba, where now he carries out his research and consultancy activities. He has been responsible for the direction of around 40 research projects. He has held different positions and responsibilities in the Spanish R\&D Management System. The results of his research activity have been published in 25 books, 45 chapters in collective books, 29 articles published in scientific journals and around 40 Technical Reports with the results of applied research projects.

Tiago Santos Pereira is a Research Fellow at the Centre for Social Studies (CES), of which he was its Executive-Director between 2006 and 2008. With a DPhil in Science and Technology Policy Studies, from SPRU, University of Sussex, his research is presently focused on the issues of the governance of science and technology. He is developing work at the intersection of Science and Technology Studies (STS) and Innovation Studies. He develops his research in CES under the Research Group on Science, Economy and Society (NECES), of which he is co-coordinator. His work has been published in national and international journals and books, and he has served as a reviewer for different international journals. 